\title{
THE TRIAD "EVALUATION, RECOGNITION AND PRESENTATION" IN THE CASE OF BIOLOGICAL ASSETS SPECIFIC TO AGRICULTURAL HOLDINGS
}

\author{
Assistant Ph.D. Student Sorin-Constantin Deaconu, University, 1 Decembrie 1918” Alba Iulia \\ e-mail: deaconu_sorin@yahoo.com
}

Abstract: The paper will present the concept of evaluation, recognition and presentation of biological assets specific to the sector of agriculture.

Evaluation is a form of quantification through which the accounting method determines the size of patrimonial elements in a natural expression and expresses this measure as a value, by means of currency. The paper will take into discussion a few particularities of evaluating biological assets.

The recognition is the process that consists in the incorporation of elements that make the patrimonial mass of entities into the balance sheet or into the profit and loss account.

In addition, the paper will present some examples of biological assets in the vision IAS 41 Agriculture. It also presents the views of the Romanian and international normative body regarding the accounting method for assets specific to agricultural holdings. The article addresses accounting assets specific to the sector of agriculture with its two large elements: plant growing and animal production. We will also present excerpts from the balance sheet and the account of profit and loss in the vision of the Romanian normative bodies and excerpts from the balance sheet and from the profit and loss account in the vision of IAS 41 Agriculture.

The expression recognition is mentioned in the international accounting standards and can be define as the existence of the financial situations elements, namely the goods, the expenses and the incomes. More exactly, he designates the generator fact of the appearance of patrimony elements, it explains the criteria on which the element is registered in the current accounting and it is reported then in the annual ${ }^{1}$ financial situations.

An agricultural exploitation must be recognized as a biological asset or an agriculture product whenever:

- the entity controls the asset as the result of the past events;

- it is likely that the future economic benefits, associated to the asset to run towards the entity

- the right value or the asset cost can be evaluated in a credible way ${ }^{2}$

After it has been taken the decision that an element that compounds the financial situations should be recognized, it is necessary to measure the value of it, as a previous operation before registration and presentation in the financial situation compounds, respectively the statement of account, assets account and losses etc. specific ${ }^{3}$ steps.

The evaluation consists in the expressing of an opinion over the value through some

We can conclude that evaluation is a form of quantification through which the method of accounting determines the weight of the patrimony elements in natural expression and it express the value of this with the help of the monetary standard. In this way the evaluation assures the

\footnotetext{
${ }^{1}$ Dumitru Matis (coordinator) s.c, Bases of Accounting-theoretical and practical aspects, Publishing House Alma Mater, Cluj Napoca, 2005, p.144.

${ }^{2}$ IAS 41 Agriculture, Paragraph 10.

${ }^{3}$ Adela Deaconu, Affairs evaluation, Publisher House Intelcredo, Cluj-Napoca, 2002, p. 7.
} 
centralization of elements, as a result of the unitary of all the accounting information expressed through the monetary standard. Without using the evaluation it cannot be used the verification balance of accounts, and it can not be presented the unitary financial position and the flux to and from the entity. In this way the evaluation assures the supposed condition of the entire flux and accounting information, which allows from the singular information expressed in the natural standard, to generate information, of synthesize, in value expression, or only of value, necessary in the decisional ${ }^{4}$ processes.

The evolution presumes to choose a kind of evaluation base. Different evaluation bases are used in financial situations, in different combinations and degrees and we say that no evaluation base has the general validity and it is not satisfactory ${ }^{5}$.

In another vision the evaluation way finds the entire papers, manners and techniques to scour the steps of the evaluation process as a method of evaluation ${ }^{6}$.

A biological asset it will be evaluated at the initial reconnaissance and every time of the balance at the right value minus the costs estimated at selling excepting the situation when the right value cannot be evaluated in a credible ${ }^{7}$ way.

At the initial reconnaissance of a biological asset there can be losses and incomes, for example when a calf ${ }^{8}$ is born.

When it comes to the point of presenting the accounting information through the financial situations any user reports on the balance sheet. From accounting point of view the animals and the plantation are on the position 08 of the balance sheet entitled Technical installations and machines. Further on we will present an excerpt from the balance sheet approved through OMFP nr. $1752 / 2005$ in order to identify the biological asset from an entity patrimony:

\section{Balance sheet excerpt \\ (According to OMFP nr. 1752/2005)}

Table 1

\begin{tabular}{|l|r|r|}
\hline \multirow{2}{*}{ Elements } & \multicolumn{2}{|c|}{ Balance at: } \\
\cline { 2 - 3 } & $\begin{array}{c}\text { The beginning } \\
\text { of the year }\end{array}$ & $\begin{array}{c}\text { At the end of } \\
\text { the year }\end{array}$ \\
\hline Immobilizations of capital & & \\
\hline 1 Land and constructions & 10.070 .145 & 9.649 .943 \\
\hline $\begin{array}{l}\text { 2 Technical installations and } \\
\text { machines }\end{array}$ & 3.676 .457 & 4.420 .870 \\
\hline $\begin{array}{l}\text { 3 Other installations, } \\
\text { machines and furniture }\end{array}$ & 119.769 & 67.009 \\
\hline $\begin{array}{l}\text { 4 Advances and } \\
\text { immobilizations of capital }\end{array}$ & 300.892 & 5.138 .886 \\
\hline Sum & 14.167 .263 & 19.276 .708 \\
\hline
\end{tabular}

Addressees of accounting information can be confused in the moment when they use data from the balance sheet presented above in the way that it can not identify the agricultural assets from exploitation. We consider useful that the Romanian legislator should come over the

\footnotetext{
${ }^{4}$ C.G. Demetrescu, V. Puchita, L. V. Voica, Accounting-fundamental and applicative science, Publisher House Scrisul Românesc, Craiova, 1979, p.230.

${ }^{5}$ Mihai Ristea (coordinator)s.c., Financial Accounting of Enterprise, University Publisher House, Bucuresti,2004,p.37.

${ }^{6}$ Vasile Dobrota, Economic Development and Reorganization- theory, evaluation, accounting reflection, Publisher House Teora, Bucuresti, 2004, p.70.

${ }^{7}$ IAS 41, paragraph 12.

${ }^{8}$ IAS 41, paragraph 27.
} 
presentation of the immobilization of capital in the balance sheet and to assign at least a separate job entitled "Animals and Birds". In this way the memorandum nr.1 Immobilized assets should be adapted in the way to present the separately the brut value of animals and farm crops, and also the adjustments of this. This kind of financial situations can provide information much more complex and useful regarding the assets that are a part of the patrimony of an agricultural exploitation.

Further on we will present some of the practical applications regarding the way of knowing in accounting of which solution we have in the IAS 41 Agriculture.

Entity 1 - application: The entity buys a herd of sheep with 125.426 lei. The buying costs can be considered a good estimation of the right value of the animals. In the situation on which the entity will sell immediately the sheep, she will support expenses in sum of 2.368. According with the international law IAS 41 Agriculture, the initial accounting can be done in this way:

\begin{tabular}{lrr}
\hline \multicolumn{1}{c}{$\%$} & 125.426 \\
„Sheep” & 123.058 \\
„Losses from the & 2.368 \\
biological assets" & \\
\hline
\end{tabular}

Entity 2 application: A farm buys 10 guarding dogs in order to oversee the farm, buying price 2.546 lei / animal.

$\overline{\text {,Dogs" }}=\overline{\text { „Debts" }}$

Entity 3- application: A cow belonging to the farm has delivered a calf, of which right value is 245 lei.

$\overline{\text { „Calves” }}=\overline{\text { „Profits from biological assets” }}$

Entity 4 application. A bee house is bought with 21.326 lei, transport expenses 1.425 lei. They gather honey during the accounting period of time evaluated with a production cost of 8.429 lei.

The registrations according with the international law IAS 41 Agriculture are:

\begin{tabular}{|c|c|}
\hline „The purchasing of the beehive" & $=$ „The final products" \\
\hline „Honey” & $\begin{array}{l}\text { "Incomes from the } \\
\text { agriculture production" }\end{array}$ \\
\hline
\end{tabular}

Registrations according with the Romanian laws similar with the ones presented above

Entity 5 application. An agriculture entity owns an apple orchard evaluated at the end of the financial exercise $\mathrm{N}$ to 285.479 lei. At the end of the exercise $\mathrm{N}+1$ the right value is 325.652 lei

\begin{tabular}{ll}
\hline "Apple orchards" & $=\begin{array}{l}\text { „Incomes from the } \\
\text { biological } 9 \text { assets" }\end{array}$ \\
\hline
\end{tabular}

\footnotetext{
${ }^{9}$ The growing of the right value as a gain, according to IAS 41 Agriculture.
} 
Entity 6 - application. A farm owns a cherry trees orchard evaluated at the end of the financial exercise $\mathrm{N}$ to 123.689 . At the end of the exercise $\mathrm{N}+1$ the right value is 96.478 lei

$\overline{\text { „Losses from biological assets” }}=\overline{\text { „Cherry trees orchard"10 }}$

Entity 7 - application. An entity owns 40 ha of grape-vine. For the crop of grapes from the year $\mathrm{N}$ ii was estimated a right value minus the costs estimated on the buying moment.

\begin{tabular}{|c|c|}
\hline „Grapes supplies" & $=\begin{array}{l}\text { "Incomes from the } \\
\text { agricultural production }{ }^{11, "}\end{array}$ \\
\hline
\end{tabular}

Entity 8-application. An entity get subsides in order to cultivate a land of cabbage (year $\mathrm{N}$ ) in the sum of 26.371. In the situation in which in the next 5 years the cultivation will stop, the subsidy must be returned.

The entering according with the international laws IAS 41 Agriculture are:

- Getting the subsidy in the year $\mathrm{N}$

$\overline{\text { „Available found" }}=\overline{\text { „Agriculture subsides" }}$

- The transfer of subsidy at the incomes:

\begin{tabular}{cl}
$\frac{\overline{\text { Agriculture subsides }}}{\text { „Agriculture subsides" }}=\frac{\begin{array}{l}\text { Incomes from the agriculture subsides } \\
\text { „Incomes from the } \\
\text { agriculture subsides" }\end{array}}{26.371^{12}}$ & \\
\hline
\end{tabular}

Registrations according with the Romanian laws similar with the ones presented above

Entity 9 - application. During a month the incomes were 12.1351 of milk. The right value minus the costs estimated on the buying moment is 21.843

\begin{tabular}{|c|c|}
\hline „Supplies / cow milk” & $=\begin{array}{l}\text { "Incomes from the } \\
\text { agriculture production }\end{array}$ \\
\hline
\end{tabular}

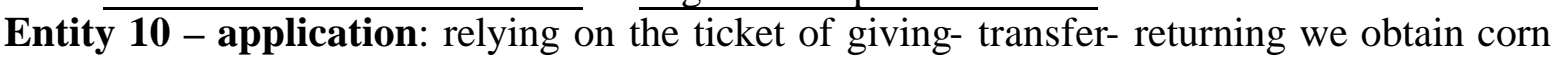
evaluated at 87.356 lei.

According with the international laws IAS 41 Agriculture the evidence is made like this:

\begin{tabular}{lll}
\hline "Corn" & $\begin{array}{l}\text { „Incomes from the } \\
\text { agriculture production ” }\end{array}$ \\
\hline
\end{tabular}

\footnotetext{
${ }_{10}^{10}$ According to the Romanian law the operation is registered like a justification for the value losses.

${ }^{11}$ The agriculture products groped will be evaluated at the right value minus the estimated costs at the selling point. Such an evaluation is the cost at that time when IAS 41 Stocks is applied (IAS 41, paragraph 13).

${ }^{12}$ A subsidy in relation with a biological asset evaluated at the right value minus the estimated costs at the selling point is the condition of all obligations (within 5 years), agriculture exploitation admits the subsidy as an income, only when the imposed conditions are accomplished.
} 
The production cycle in which the corn crops are made, extends on two financial exercises. In the first year sets up the corn crop, the nest year will be done the maintenance of the works and will be the crop.

In the same time it must be done the production registered earlier, that points out the value of the expenses made in order to realize the crop (fuel expenses, the tilling the expenses made on the sow the expenses made with the weed killer, the salaries etc.)

\section{Conclusions and suggestions}

We presented the principal characteristics of the two bases of evaluation: the historical cost and the right value. We deduced that the international laws foresees the separate evaluation of the biological assets of agriculture products, and this represents one of the reasons that leaded to the IAS 41 Agriculture, because it completes the accounting treatments foresee in the IAS 2 Supplies. A possible disputable alternative which we propose is the one in which the two international accounting laws (IAS 2 AND IAS 41) should become one and this one law to contain both the supplies and the biological assets.

We consider useful the Romanian legislator become over the presentation of the immobilization of capital in the balance sheet and to assign at least a separate job entitled "Animals and Birds". In this way the memorandum nr.1 Immobilized assets should be adapted in the way to present the separately the brut value of animals and farm crops, and also on the adjustments of this. This kind of financial situations can provide information much more complex and useful regarding the assets that are a part of the patrimony of an agricultural exploitation.

Also, in the paper were presented some particular cases regarding the way the agricultural assets are registered from the perspective of IAS 41 Agriculture, as from the point of the Romanian laws. We find the there are differences between the ways of evident especially when recognizing the initial assets. So the international law operates with the right value and with the initial recognizing can appear losses from the biological assets, that represents the expenses with the selling immediately of assets. According with the Romanian laws, the losses from the biological assets are not mentioned at first and the operations are made with the evaluation from the level of historical cost.

\section{Bibliography}

1. Demetrescu C.G., Puchita.V., Possler L., Voica V., Accounting- fundamental and applicative science, Publisher House Scrisul Românesc, Craiova,1979.

2. Dobrota Vasile, Economic Development and Reorganization - theory, evaluation, accounting reflection, Publisher House Teora, Bucuresti, 2004.

3. Feleaga Niculae, Malciu Liliana, Recognition, evaluation and estimation in the international accounting, Publisher House CECCAR, Bucuresti, 2004.

4. Matis Dumitru, Bases of Accounting- theoretical and practical aspects, Publishing House Alma Mater, Cluj-Napoca, 2005.

5. Pântea Iacob Petru, Bodea Gheorghe, Romanian Financial Acounting according to the international directions, Publisher House Intelcredo, Deva 2002.

6. Pop Atanasiu, Romanian accounting harmonized with the international norms, international standards of accounting, Publisher House Intelcredo, Deva, 2002.

7. Ristea Mihai, Financiar Accounting of Enterprise, University Publisher House, Bucuresti, 2004.

8. International standards of financial reporting including The International standards of accounting and the interpretation at January the first 2006, Publisher House CECCAR, Bucuresti, 2006. 